\title{
Nitrogen fertilisation of durum wheat: a case study in Mediterranean area during transition to conservation agriculture
}

\author{
Angelica Galieni, ${ }^{1}$ Fabio Stagnari, ${ }^{1}$ Giovanna Visioli, ${ }^{2}$ Nelson Marmiroli, ${ }^{2}$ Stefano Speca, ${ }^{1}$ \\ Giovanni Angelozzi, ${ }^{1}$ Sara D'Egidio, ${ }^{1}$ Michele Pisante ${ }^{1}$ \\ ${ }^{1}$ Faculty of Biosciences and Technologies for Agriculture Food and Environment, University \\ of Teramo; ${ }^{2}$ Department of Life Sciences, University of Parma, Italy
}

\begin{abstract}
Nitrogen (N) nutrition plays a key role for high yields and quality in durum wheat (Triticum turgidum L. subsp. durum (Desf.) Husn); in Mediterranean environments, data regarding $\mathrm{N}$ fertilisation management during the transition phase to conservation agriculture (CA) are limited. The aim of this work was to study the effects of $\mathrm{N}$ fertiliser forms and rates on yield and some quality traits of durum wheat, during the transition period to CA in Mediterranean areas; moreover, indication on the recommendable $\mathrm{N}$ form/rate combinations have been given. Field trials were carried out in south of Italy, during the first two years of transition to CA (from 2010 to 2012) in a durum wheat-based rotation. Following a split-plot design arranged on a randomised complete blocks with three replications, two $\mathrm{N}$ forms (main plots) - urea and calcium nitrate - and four $\mathrm{N}$ rates (sub-plots) - 50, 100, 150 and $200 \mathrm{~kg} \mathrm{~N} \mathrm{ha}^{-1}$ - plus an un-fertilised Control, were compared. The following parameters were analysed: grain yield, $\mathrm{N}$-input efficiency,
\end{abstract}

Correspondence: Fabio Stagnari, Faculty of Bioscience and Technologies for Food, Agriculture and Environment, University of Teramo, via Carlo Lerici 1, I-64023 Teramo, Italy.

Tel.: +39.0861266914.

E-mail: fstagnari@unite.it

Key words: Nitrogen fertilisation strategies; durum wheat; conservation agriculture; glutenins; gliadins.

Acknowledgements: the authors kindly acknowledge Urbana Bonas for technical assistance in performing proteins' extractions and quantifications. This work was supported by Progetto AGER, grant no. 2010C21J10000660002.

Contributions: all the authors contributed equally to the work.

Conference presentation: SIA XLIII Congress, Pisa, 2014.

Received for publication: 6 February 2015.

Revision received: 29 June 2015.

Accepted for publication: 4 August 2015.

(C) Copyright A. Galieni et al., 2016

Licensee PAGEPress, Italy

Italian Journal of Agronomy 2016; 11:662

doi:10.4081/ija.2016.662

This article is distributed under the terms of the Creative Commons Attribution Noncommercial License (by-nc 4.0) which permits any noncommercial use, distribution, and reproduction in any medium, provided the original author(s) and source are credited. grains protein concentration (GPC), total gluten, gluten fractions and minerals concentration in kernels. Calcium nitrate gave the highest yield (4.48 $\mathrm{t} \mathrm{ha}^{-1}$ ), as predicted by the quadratic model, at $146 \mathrm{~kg} \mathrm{~N} \mathrm{ha}^{-1}$, on average. This was particularly noticeable in 2012, when the distribution of rainfall and temperatures regimes as well as residues' status could have favoured such $\mathrm{N}$-form. These results were confirmed by the observed higher values of all indices describing $\mathrm{N}$-input efficiency. High GPC values (14.8\%) were predicted at slightly higher N-rates (173 kg N ha ${ }^{-1}$, averaging both $\mathrm{N}$ forms). In particular, gluten proteins and glutenin/gliadin ratio accrued as the $\mathrm{N}$ doses increased, reaching the highest values at $150 \mathrm{~kg} \mathrm{~N} \mathrm{ha}^{-1}$, also positively affecting the quality of durum wheat flour. Iron and zinc concentrations were noticeably increased (38\% and $37 \%$ on average) by $\mathrm{N}$ supply, probably due to the enhanced water use efficiency under CA systems.

Principal component analysis summarised properly the obtained results: analysing the $\mathrm{N}$-rates at $150 \mathrm{~kg} \mathrm{~N} \mathrm{ha}^{-1}$, it was confirmed that yields and quality characteristics of durum wheat were optimised in the wettest year (2011) with calcium nitrate. Moreover, the scarce amount of residues characterising the transition phase to $\mathrm{CA}$, requires $\mathrm{N}$ application rates not lower than $150 \mathrm{~kg} \mathrm{ha}^{-1}$ in order to ensure stable yields and important quality traits. These $\mathrm{N}$ rates should be modulated as the accumulation of crop residues increases over time, thanks to long-term effects of CA on soil chemical, physical and biological properties.

\section{Introduction}

Southern Europe's environment is characterised by cool and wet winters and hot and dry summers with low and erratic rainfall distribution, and by soils with very low organic matter levels and nitrogen (N) content. Nitrogen is subjected to several losses with the main pathways being represented by ammonia volatilisation, denitrification and nitrate leaching (Plaza-Bonil et al., 2014). Moreover, in these environments agricultural systems depend mainly on winter crops; with limited alternatives, farmers rely on short rotations based on durum wheat (Triticum turgidum L. subsp. durum (Desf.) Husn.), and rarely on sunflower (Helianthus annuus L.) and faba bean (Vicia faba L.). This cereal crop contributes significantly as a source of carbohydrate and it is a potential contributor of micronutrients and proteins in human diets, which has led to a renewed interest in whole meal durum-based products. Mineral elements have been suggested to have an important role in maintaining good health (Buri et al., 2004), as well as proteins. Proteins concentration in kernels is clearly conditioned by environmental variables such as water availability and temperature during growth, especially through the grain-filling period (Tea et al., 2004), which influence the rate and duration of wheat grain development, protein accumulation and starch deposition (Ottman et al., 2000; Dupont and Altenbach, 2003). However, the most effective 
environmental factor on protein accumulation is $\mathrm{N}$ availability; recent data on wheat underlined the effects of $\mathrm{N}$ also on the modification of wheat gluten protein composition, with respect to single members of gliadin and to the high and low molecular weight glutenins (HMW-GS, LMW-GS) (Hurkman et al., 2013; Wan et al., 2013; Visioli et al., 2016).

Conservation agriculture (CA), among the greener solutions currently being discussed (García-Torres et al., 2003; Gilbert, 2012), has the potential of mitigating the negative effects of soil fertility losses and climate changes (Pisante, 2007; Kassam et al., 2009; Stagnari et al., 2010; Pisante, 2013). In general under CA, soil and water conservation are increased, the soil physical and chemical properties as well as its biological activity are improved, and consequently the $\mathrm{N}$ losses are reduced (Deng et al., 2006); however, under particular conditions $\mathrm{N}$ losses in no-tillage systems could increase compared to tillage-based ones (Mackenzie et al., 1998; Baggs et al., 2003). Moreover, the transition phase to CA is very complex and may influence negatively the farmers; weeds and fertilisation management represent major issues (Knowler and Bradshaw, 2007) and soil physical and biological health takes time to develop. In such conditions, yield of durum wheat could be inconsistent, depending on soil-climatic characteristics and on a number of interacting factors, including residue management, cultural practices and drill performance (Gemtos et al., 1998). Consequently, N fertilisation strategies need to be adequately adjusted, combining rate, timing, splitting, and source of $\mathrm{N}$ application, with the aim of optimising yield and its quality (Abedi et al., 2010). Indeed, by adopting CA, thanks to the improved soil surface covering, water capture and retention are enhanced, thus increasing crop growth and $\mathrm{N}$ uptake. This may reduce the availability of soil mineral $\mathrm{N}$ and may require an increasing in $\mathrm{N}$ fertilisation (Morell et al., 2011). Few studies indicate that slightly higher doses of fertiliser are required to achieve significant yields in winter wheat in presence of a layer of surface residues (Gao et al., 2009 ), especially under long-term periods ( $>10$ years) of CA adoption.

In durum wheat-based agricultural systems of the suited Mediterranean areas, studies investigating the effect of $\mathrm{N}$ fertilisation management on yield and quality of this crop, during the transition phase to CA are lacking; in addition, the scientific literature does not provide devised recommendations on the optimum $\mathrm{N}$ rates and forms to be applied in these conditions. This dearth of data was the catalyst to this research; the aim was to study the effects of $\mathrm{N}$ nutrition on durum wheat yield and some quality traits such as, HMW-GS, LMW-GS and gliadin content, minerals accumulation during the transitional phase from conventional agriculture to $\mathrm{CA}$, in Mediterranean environments; moreover, indication on the suitable combination of $\mathrm{N}$ form and rate are given.

\section{Materials and methods}

\section{Site description}

A two-year field experiment was carried out during 2010-2011 and 2011-2012 growing seasons (referred below as 2011 and 2012, respectively) at the experimental field of the University of Teramo (Mosciano Sant'Angelo, Italy, $42^{\circ} 42^{\prime} \mathrm{N}, 13^{\circ} 52^{\prime} \mathrm{E}, 101 \mathrm{~m}$ a.s.l.). The climate is typically Mediterranean with a mean of annual rainfall, recorded over a 58-year period, of $732 \mathrm{~mm}$ mainly concentrated between October and April. The means of the maximum and minimum temperatures range from $11^{\circ} \mathrm{C}$ to $29^{\circ} \mathrm{C}$ and from $2{ }^{\circ} \mathrm{C}$ to $17^{\circ} \mathrm{C}$, respectively. The soil is a typical medium-clay soil with the follows characteristics: $23 \%$ sand, $45 \%$ silt, $32 \%$ clay, $1.36 \%$ o.m., pH 8.1, $19 \%$ total $\mathrm{CaCO}_{3}, 10.6 \%$ active $\mathrm{CaCO}_{3}$, $0.16 \%$ total $\mathrm{N}$ and $3211 \mathrm{ppm}$ CEC.

Meteorological data were recorded by a meteorological station situ- ated $\sim 1 \mathrm{~km}$ from the experimental field. Minimum, maximum, average temperatures and rainfall referred to the whole crop cycles are reported in Figure 1.

\section{Crop management and experimental design}

Conservation agriculture methods were first imposed in 2010. Soil was subjected to no-till management, with repeated reuse of existing beds, which were reformed in the furrows without disturbance of the tops of the beds as needed. The preceding crops were coriander (Coriandrum sativum L.) in 2011 and wheat in 2012, which were harvested at the end of July and at the middle of June, respectively. The amount of crop residues $\left(2.9 \mathrm{t} \mathrm{ha}^{-1}\right.$ and $7.0 \mathrm{t} \mathrm{ha}^{-1}$ on average for coriander and wheat, respectively) was estimated by collecting and weighting the leaves and stems on 10 randomly selected sub-units $\left(0.25 \mathrm{~m}^{2}\right)$ in the experimental area. The nitrogen content in vegetative organs was determined with the Kjeldahl method, while the organic carbon (C) content was determined following the Walkley and Black procedure (Walkley and Black, 1934). Wheat straw contained $0.42 \% \mathrm{~N}$ while coriander $1.54 \%$ with a $\mathrm{C}: \mathrm{N}$ ratio of 107.3 and 29.9 , respectively. Crop residues were kept on the soil surface and homogenously distributed in order to obtain a uniform layer of mulch and without interfering with the subsequent sowing operations. Two weeks before sowing, glyphosate (45\%) were applied at the rate of $2 \mathrm{~L} \mathrm{ha}^{-1}$. Durum wheat (Triticum turgidum L. subsp. durum (Desf.) Husn., cv Achille) was sown on mid-November (8/11/2010 and 17/11/2011) by direct seeding [Gaspardo Direttissima, Gruppo Maschio Gaspardo SpA, Campodarsego (PD), Italy], at a rate of 350 viable seeds $\mathrm{m}^{-2}$. This sowing density is recommended for durum wheat modern cultivars in Mediterranean environments to obtain a density of about 300-400 ears $\mathrm{m}^{-2}$. The experimental design consisted in a split-plot arranged on a randomised complete blocks with three replications. Two forms of $\mathrm{N}$ (urea and calcium nitrate), represented the main plots, and four levels of $\mathrm{N}$ rates $\left(50,100,150\right.$ and $\left.200 \mathrm{~kg} \mathrm{~N} \mathrm{ha}^{-1}\right)$ the sub-plots; an $\mathrm{N}$-unfer-

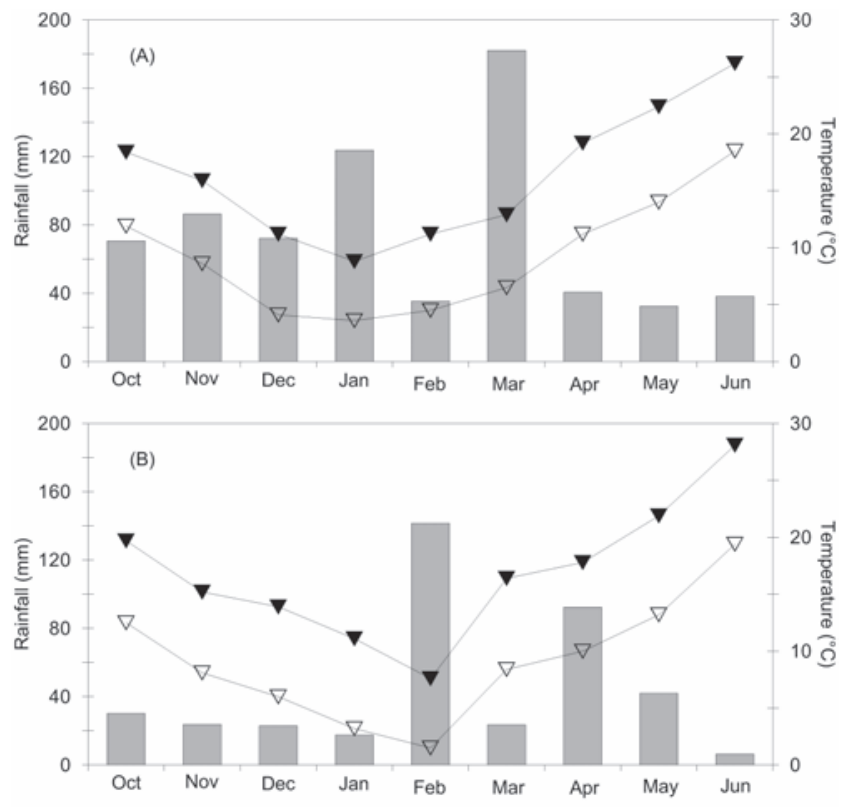

Figure 1. Rainfall (bars), maximum (black symbols) and minimum (empty symbols) temperatures during 2010/2011 (A) and 2011/2012 (B) growing seasons, registered at Teramo (Italy). Rainfall values represent sums, and temperature values means, over one month period. 
tilised treatment was also included within each main plot as control (CONTROL). The experimental units (sub-plots) were of a $24 \mathrm{~m}^{2}$ (3x8 m) with 17 rows spaced $17 \mathrm{~cm}$ apart. For all treatments (including CONTROL) the pre-sowing inputs included $96 \mathrm{~kg} \mathrm{ha}^{-1}$ of $\mathrm{P}_{2} \mathrm{O}_{5}$ as single super phosphate $\left(16 \% \mathrm{P}_{2} \mathrm{O}_{5}\right)$; $\mathrm{N}$ fertilisation was performed on all $\mathrm{N}$-fertilised treatments (excluding CONTROL) and fractioned as follows: $20 \%$ of the expected $\mathrm{N}$ dose as pre-sowing fertilisation, while the remaining $80 \% \mathrm{~N}$ was applied as cover dressing in equal amount on two dates: at tillering and at $4^{\text {th }}$ node detectable stages (DC22 and DC34, following the Zadoks Decimal Code; Zadoks et al., 1974). Fertilisers were homogenously and carefully distributed in order to ensure the highest uniformity. At the phenological stage of mid-tillering, postemergence applications of Atlantis [active ingredients (a.i.) mesosulfuron-methyl, iodosulfuron-methyl-sodium and mefenpir-diethyl; Bayer CropScience Italia, Milan, Italy] at the dose of $0.5 \mathrm{~kg} \mathrm{ha}^{-1}$, Biopower (a.i. 3,6-dioxaoctadecylsulphate sodium salt and 3,6-dioxaeicosylsulphatesodium salt; Bayer CropScience Italia) at the dose of $1 \mathrm{~L} \mathrm{ha}^{-1}$ and Zenith (a.i. fluorasulam and 2,4-D; Dow AgroSciences Italia, Bologna, Italy) at the dose of $0.75 \mathrm{~L} \mathrm{ha}^{-1}$ were performed to control both broadleaf and graminaceous weeds. Fungicide Sphere (trifloxystrobin and cypro-conazole; Bayer CropScience Italia) was applied at the dose of $1 \mathrm{~L} \mathrm{ha}^{-1}$ at DC50 stage.

\section{Plant sampling, yield and biomass $\mathrm{N}$ determination}

At harvest (on June 23 and 20 in 2011 and 2012, respectively), five sub-samples of $1 \mathrm{~m}$ linear raw of whole plants were randomly collected to determine total dry matter, yield - by weighting the amount of kernels from each plot - and organs nitrogen concentration, determined with the Kjeldahl method. Grains protein concentration (GPC, \%) was calculated as grain $\mathrm{N}$ concentration multiplied by 5.7 (Sosulski and Imafidon, 1990).

Nitrogen uptake $\left(N_{g}\right)$ was estimated by multiplying grain and straw weight with the respective values of $\mathrm{N}$ concentrations for a particular treatment. According to Novoa and Loomis (1981) and Craswell and Godwin (1984), the following parameters were calculated as follows: i) apparent $\mathrm{N}$ recovery (ANR, \%): as the ratio of $\left(N_{g}\right.$ at $N_{x}-N_{g}$ at $\left.N_{0}\right)$ to applied $\mathrm{N}$ at $N_{x}$; ii) physiological efficiency $\left(\mathrm{P}_{\mathrm{E}}\right)\left(\mathrm{kg} \mathrm{kg}^{-1}\right)$ : as the ratio of (grain yield at $N_{x}$ - grain yield at $\left.N_{0}\right)$ to $\left(N_{g}\right.$ at $N_{x}-N_{g}$ at $\left.N_{0}\right)$; iii) agro-

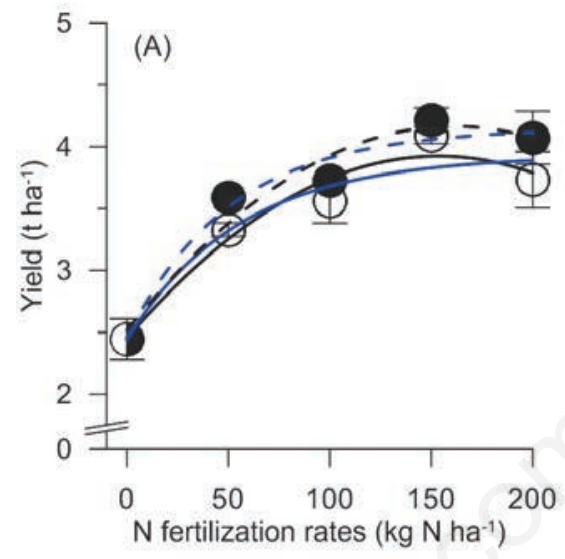

\begin{tabular}{|c|c|c|c|c|}
\hline Coefficients & Urea & & Calcium Nitrate & \\
\hline \multicolumn{5}{|l|}{ Quadratic model } \\
\hline$\beta_{0}$ & $2.45 \pm 0.132$ & *** & $2.51 \pm 0.111$ & $* * *$ \\
\hline $\boldsymbol{\beta}_{1}$ & $0.02 \pm 0.003$ & $* * *$ & $0.02 \pm 0.003$ & $* * *$ \\
\hline $\boldsymbol{B}_{2}$ & $-6.29 \mathrm{e}^{-05} \pm 1.50 \mathrm{e}^{-05}$ & ** & $-6.38 \mathrm{e}^{-05} \pm 1.26 \mathrm{e}^{-05}$ & $* * *$ \\
\hline$R^{2}$ & 0.95 & & 0.95 & \\
\hline RSS & 0.710 & & 0.502 & \\
\hline$s^{2}$ & 0.059 & & 0.042 & \\
\hline \multicolumn{5}{|c|}{ Exponential model } \\
\hline$\beta_{0}$ & $3.93 \pm 0.166$ & $* * *$ & $4.15 \pm 0.109$ & $* * *$ \\
\hline$\beta_{1}$ & $0.02 \pm 0.007$ & $*$ & $0.02 \pm 0.005$ & $* *$ \\
\hline $\boldsymbol{B}_{2}$ & $54.12+20.207$ & $*$ & $45.85 \pm 10.709$ & $* *$ \\
\hline$R^{2}$ & 0.93 & & 0.97 & \\
\hline RSS & 0.825 & & 0.422 & \\
\hline$s^{2}$ & 0.069 & & 0.035 & \\
\hline \multicolumn{5}{|c|}{$\begin{array}{l}\cdot P<0.1 ; \bullet P<0.05 ; \cdot \bullet P 0.01 ; \cdots P<0.001 ; n . s .=\text { not-significant } \\
R S S=\text { Residual sum-of-squares } \\
S^{2}=\text { Residual mean square }\end{array}$} \\
\hline Coefficients & Urea & & Calcium Nitrate & \\
\hline \multicolumn{5}{|l|}{ Quadratic model } \\
\hline$\beta_{0}$ & $2.10 \pm 0.162$ & $* * *$ & $2.25 \pm 0.194$ & $* * *$ \\
\hline $\boldsymbol{\beta}_{\mathbf{1}}$ & $0.02+0.004$ & $* * *$ & $0.04 \pm 0.005$ & $* * *$ \\
\hline$\beta_{2}$ & $-6.25 \mathrm{e}^{-0.5} \pm 1.84 \mathrm{e}^{-0.5}$ & $\approx *$ & $-1.32 \mathrm{e}^{-0.4} \pm 2.21 \mathrm{e}^{-0.5}$ & $* * *$ \\
\hline$R^{2}$ & 0.97 & & 0.94 & \\
\hline RSS & 1.071 & & 1.540 & \\
\hline$s^{2}$ & 0.089 & & 0.128 & \\
\hline \multicolumn{5}{|l|}{ Exponential model } \\
\hline$B_{0}$ & $4.76 \pm 0.395$ & $* * *$ & $4.47 \pm 0.103$ & $* * *$ \\
\hline$\beta_{1}$ & $0.01 \pm 0.004$ & $*$ & $0.04 \pm 0.011$ & $* *$ \\
\hline $\boldsymbol{B}_{2}$ & $53.82 \pm 17.215$ & $* *$ & $16.16 \pm 4.829$ & $* *$ \\
\hline$R^{2}$ & 0.97 & & 0.99 & \\
\hline RSS & 1.119 & & 0.884 & \\
\hline$s^{2}$ & 0.093 & & 0.074 & \\
\hline
\end{tabular}

Figure 2. Durum wheat yield $\left(\mathrm{t} \mathrm{ha}^{-1}\right)$ against nitrogen $(\mathrm{N})$ fertilisation rates $\left(0,50,100,150\right.$ and $\left.200 \mathrm{~kg} \mathrm{~N} \mathrm{ha}^{-1}\right)$ in $2011(\mathrm{~A})$ and 2012 (B). Empty symbols stand for urea, black symbols stand for calcium nitrate. Data are averages \pm standard errors, for $n=3$ independent replicates. On the right, the corresponding parameters of the fitted quadratic (black lines) and exponential (blue lines) models. Solid lines, urea; dashed lines, calcium nitrate. 
nomic efficiency $\left(\mathrm{A}_{\mathrm{E}}\right)\left(\mathrm{kg} \mathrm{kg}^{-1}\right)$ : as the ratio of (grain yield at $N_{x}$ - grain yield at $N_{0}$ ) to $\mathrm{N}$ applied at $N_{x}$.

\section{Gluten proteins extraction and quantification}

Thirty-five $g$ of grains from each treatment were crushed with Knifetec TM 1095 (Foss, Hillerød, Denmark) to obtain a fine powder and used to analyse the composition of gliadin, HMW-GS and LMW-GS fractions. Gluten proteins were extracted from wheat flour by using a modification of the sequential procedure of Singh et al. (1999). Fine powder (30 mg) was extracted with $1.5 \mathrm{~mL}$ of $55 \%$ (v/v) propan-2-ol for 20 min with continuous mixing at $65^{\circ} \mathrm{C}$, followed by centrifugation for $5 \mathrm{~min}$ at 10,000 rpm. This step was repeated three times and the gliadin component was extracted. Pellet containing the glutenin fraction was resuspended in a solution of 55\% (v/v) propan-2-ol, $0.08 \mathrm{M}$ tris(hydroxymethyl)aminomethane hydrochloric acid $\mathrm{pH} 8.3$ and 1\% (w/v) dithiothreitol as reducing agent and incubated for $30 \mathrm{~min}$ at $60^{\circ} \mathrm{C}$ with continuous mixing. After centrifugation for $5 \mathrm{~min}$ at 14,000 rpm, the supernatant containing both HMW and LMW-GS fractions, was transferred into a new tube. Acetone was then added to reach a final concentration of $40 \%$ (v/v) to precipitate HMW-GS. The remaining supernatant was precipitated adding acetone to reach a final concentration of $80 \%(\mathrm{v} / \mathrm{v})$ and the LMW-GS fraction was recovered. Both protein fractions were dissolved in $(50: 50 \mathrm{v} / \mathrm{v})$ acetonitrile and $\mathrm{H}_{2} \mathrm{O}$ with $0.1 \%(\mathrm{v} / \mathrm{v})$ trifluoroacetic acid and quantified with the Bradford assay. Three replicates were performed for each sample.

\section{Mineral concentration}

Minerals concentrations [calcium (Ca), magnesium (Mg), potassium $(\mathrm{K})$, iron $(\mathrm{Fe})$, manganese $(\mathrm{Mn})$ and zinc $(\mathrm{Zn})]$ of collected grains were determined by atomic absorption spectrometry (Perkin-Elmer A Analyst300, Waltham, MA, USA), according to the Method 968.08 (AOAC, 1995), while phosphorus (P) was determined by the colorimetric method with molybdo-vanadate reagent (Method 965.17) (AOAC, 1995). Mineral concentration was expressed in $\mathrm{mg} \mathrm{g}^{-1}$ of grains dry matter.

\section{Statistical analysis}

Data regarding total gluten protein, glutenins, gliadins and minerals concentration in grains were plotted as a function of $\mathrm{N}$ fertilisation rates $\left(\mathrm{kg} \mathrm{N} \mathrm{ha}^{-1}\right)$ and the statistical differences between treatments were detected by comparing the means \pm standard errors.

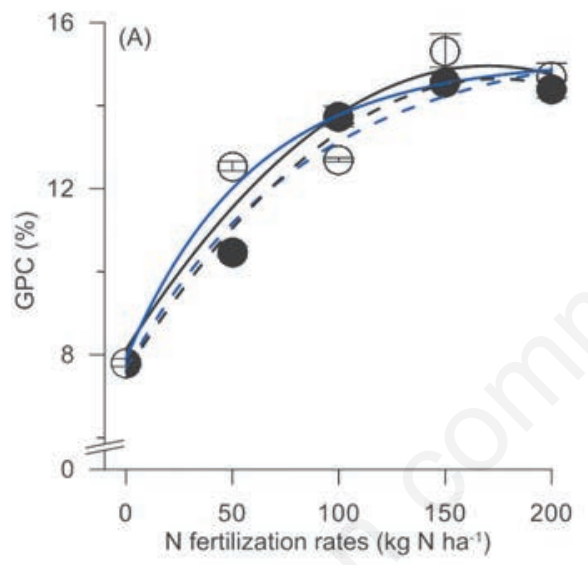

\begin{tabular}{|c|c|c|c|c|}
\hline Coefficients & Urea & & Calcium Nitrate & \\
\hline \multicolumn{5}{|l|}{ Quadratic model } \\
\hline$B_{0}$ & $8.13 \pm 0.478$ & $\cdots$ & $7.59 \div 0.246$ & $\cdots$ \\
\hline$\beta_{1}$ & $0.08 \pm 0.01$ & $* *$ & $0.08 \div 0.006$ & $\cdots *$ \\
\hline$\beta_{2}$ & $-2.35 \mathrm{e}^{-04}+5.43 \mathrm{e}^{-05}$ & $* *$ & $-2.32 e^{0.04}+2.80 e^{-05}$ & $\cdots$ \\
\hline $\boldsymbol{R}^{2}$ & 0.93 & & 0.98 & \\
\hline$R S S$ & 9.271 & & 2.461 & \\
\hline$s^{2}$ & 0.773 & & 0.205 & \\
\hline \multicolumn{5}{|l|}{ Exponential model } \\
\hline$B_{0}$ & $15.11 \pm 0.557$ & $* *$ & $15.60 \pm 0.678$ & $* *$ \\
\hline$B_{1}$ & $0.02+0.004$ & $\because$ & $0.01 \pm 0.003$ & $\ldots *$ \\
\hline$B_{2}$ & $43.90 \pm 11.161$ & $*$ & $57.20 \pm 11.321$ & $* * *$ \\
\hline$R^{2}$ & 0.94 & & 0.97 & \\
\hline$R S S$ & 8.054 & & 4.396 & \\
\hline$s^{2}$ & 0.671 & & 0.366 & \\
\hline
\end{tabular}

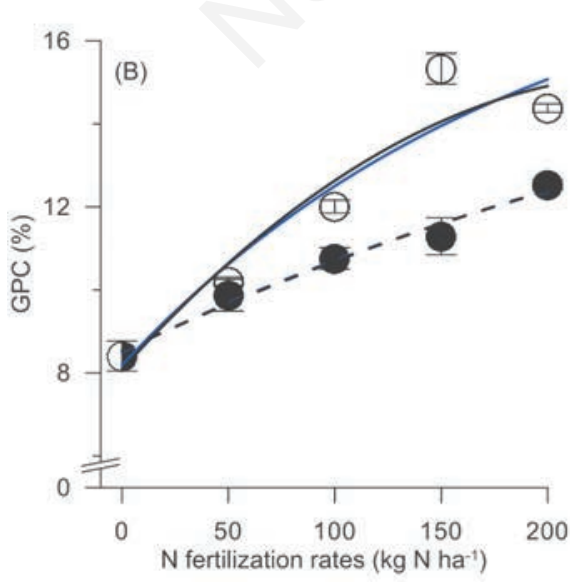

\begin{tabular}{|c|c|c|c|c|}
\hline Coefficients & Urea & & Calcium Nitrate & \\
\hline \multicolumn{5}{|l|}{ Quadratic model } \\
\hline$B_{0}$ & $8.09 \div 0.487$ & *** & $8.53 \pm 0.310$ & *** \\
\hline$\beta_{1}$ & $0.06 \div 0.01$ & $* *$ & $0.02 \pm 0.007$ & $*$ \\
\hline$B_{2}$ & $-1.13 e^{-06} \pm 5.54 e^{0.5}$ & - & $-2.31 \mathrm{e}^{-05} \pm 3.52 \mathrm{e}^{-05}$ & n.s. \\
\hline$R^{2}$ & 0.92 & & 0.98 & \\
\hline$R S S$ & 9.652 & & 3.900 & \\
\hline$s^{2}$ & 0.804 & & 0.325 & \\
\hline \multicolumn{5}{|l|}{ Exponential model } \\
\hline$B_{0}$ & $18.88 \pm 4.432$ & $*$ & $17.51 \pm 8.986$ & - \\
\hline$\beta_{1}$ & $0.005 \pm 0.003$ & ns. & $0.003 \pm 0.004$ & ns. \\
\hline$B_{2}$ & $109.50 \pm 45.30$ & $*$ & $236.60 \pm 145.30$ & ns. \\
\hline$R^{2}$ & 0.91 & & 0.98 & \\
\hline RSS & 10.400 & & 3.875 & \\
\hline$s^{2}$ & 0.867 & & 0.323 & \\
\hline
\end{tabular}

Figure 3. Durum wheat grains protein concentration (GPC) (\%) against nitrogen (N) fertilisation rates $(0,50,100,150$ and $200 \mathrm{~kg} N$ $h^{-1}$ ) in 2011 (A) and 2012 (B). Empty symbols stand for urea, black symbols stand for calcium nitrate. Data are averages \pm standard errors, for $n=3$ independent replicates. On the right, the corresponding parameters of the fitted quadratic (black lines) and exponential (blue lines) models. Solid lines, urea; dashed lines, calcium nitrate. 
Data regarding $N_{g}, \mathrm{ANR} \%, \mathrm{P}_{\mathrm{E}}$ and $\mathrm{A}_{\mathrm{E}}$ were subjected to analysis of variance (two-way ANOVA) with $\mathrm{N}$ form regarded as the main factor and $\mathrm{N}$ rates regarded as secondary factor. Before ANOVA, data were analysed to test the satisfactory of the normality and homoscedasticity assumptions. The significance level was set at $\mathrm{P}<0.05$.

In order to describe wheat yield and GPC in response to $\mathrm{N}$ fertiliser, two statistical models (negative exponential and quadratic) were fitted to the recorded data. The exponential model [i.e., the Mitscherlich model (1990)] is defined as follows (Eq. 1):

$$
Y=\beta_{0}\left(1-\left(\exp \left(-\beta_{1}\left(\mathrm{X}+\beta_{2}\right)\right)\right.\right.
$$

where $Y$ is the response variable (grain yield, $\mathrm{t} \mathrm{ha}^{-1}$ or $\mathrm{GPC}, \%$ ), $X$ is the predictor variable ( $\mathrm{N}$ fertilisation rates, $\mathrm{kg} \mathrm{N} \mathrm{ha}^{-1}$ ) and $\beta_{0}$ is the maximum yield, or GPC, when $X$ is not limiting, $\beta_{l}$ is the increase in expected yield, or GPC, per unit $X$ per unit of opportunity for yield, or GPC, to increase and $\beta_{2}$ is the nutrient value of soil in units or equivalents of $X$.

The quadratic model is defined by Eq. 2 :

$$
Y=\beta_{0}+\beta_{1} X+\beta_{2} X^{2}
$$

where $Y$ is the response variable (grain yield, $\mathrm{t} \mathrm{ha}^{-1}$ or GPC, $\%$ ), $X$ is the predictor variable ( $\mathrm{N}$ fertilisation rates, $\mathrm{kg} \mathrm{N} \mathrm{ha}^{-1}$ ) and $\beta_{0}, \beta_{1}$ and $\beta_{2}$ are the coefficients of intercept, linear and quadratic terms, respectively. For the quadratic model, the predicted maximum yield was calculated by setting the first derivative equal to zero, solving for $X$, substituting the obtained $X$ into the response equation and solving for $Y$. For the exponential model, the maximum yield approximately equals the estimated value of the intercept $\left(\beta_{0}\right)$ of the model.

The principal component analysis (PCA) was applied to interpret and summarise the correlation among variables [yield, total gluten proteins (TGP), gliadins, HMW-GS, LMW-GS, Ca, P, K, Fe, Mn and Zn] and to evaluate the relation between treatments ( $\mathrm{N}$ forms and $\mathrm{N}$ rates) and variables. In order to simplify the dimensionality of the dataset and to obtain relevant information about the main quality characteristics in relation to yield, only the $150 \mathrm{~kg} \mathrm{ha}^{-1}$ rate was considered, as well as the $\mathrm{N}$-unfertilised CONTROL. Overall, there were six treatments referring to the six year-N-form-N-rate combination: CONTROL_2011, CONTROL_2012, UREA_2011, UREA_2012, NITRATE_2011 and NITRATE_2012. The collected data were visually explored in a two dimensional PCA correlation bi-plot: standardised PC1 and PC2 scores were plotted as symbols, while the correlations between PCs and standardised variables (factor loadings) were plotted as vectors. The PCA was performed on standardised data (averages of $n=3$ independent replicates). All the statistical analyses were performed using the R software (R Foundation for Statistical Computing, Vienna, Austria) (R Development Core Team, 2013).

\section{Meteorological data}

The two growing seasons greatly differed in the amount and distribution of rainfall (Figure 1). It was particularly marked in the period ranging from sowing to anthesis: in 2011, the crops received an amount of $507.2 \mathrm{~mm}$ of rain, while in 2012 only $314.6 \mathrm{~mm}$. The difference was consistent also from anthesis to the end of grain filling, with amounts ranging from $70.8 \mathrm{~mm}$ in 2011 to $47.6 \mathrm{~mm}$ in 2012, respectively. The mean air temperature of the whole growing season was higher in 2012 of about $1.5^{\circ} \mathrm{C}\left(11.7^{\circ} \mathrm{C}\right.$ and $13.1^{\circ} \mathrm{C}$ for 2011 and 2012 , respectively).

Table 1. Nitrogen grain uptake $\left(\mathrm{kg} \mathrm{ha}^{-1}\right)$, apparent nitrogen recovery (\%), physiological efficiency $\left(\mathrm{kg} \mathrm{kg}^{-1}\right)$ and agronomic efficiency

\begin{tabular}{|c|c|c|c|c|c|c|c|c|c|}
\hline $\begin{array}{l}\text { Treatment } \\
\mathrm{N} \text { form }\end{array}$ & $\begin{array}{l}\text { N rate } \\
\left(\mathrm{kg} \mathrm{ha}^{-1}\right)\end{array}$ & $\begin{array}{l}\text { N uptake } \\
\left(\mathrm{kg} \mathrm{ha}^{-1}\right)\end{array}$ & ANR $\%$ & $\begin{array}{l}011 \\
\mathrm{P}_{\mathrm{E}} \\
\left(\mathrm{kg} \mathrm{kg}^{-1}\right)\end{array}$ & $\begin{array}{c}\mathrm{A}_{\mathrm{E}} \\
\left(\mathrm{kg} \mathrm{kg-1}^{-1}\right)\end{array}$ & $\begin{array}{l}\text { N uptake } \\
\left(\mathrm{kg} \mathrm{ha}^{-1}\right)\end{array}$ & $\begin{array}{r}20 \\
\text { ANR\% }\end{array}$ & $\underset{\left(\mathrm{kg} \mathrm{ha}^{-1}\right)}{\mathrm{P}_{\mathrm{E}}}$ & $\begin{array}{c}\mathrm{A}_{\mathrm{E}} \\
\left(\mathrm{kg} \mathrm{kg-1}^{-1}\right)\end{array}$ \\
\hline Urea & $\begin{array}{c}0 \\
50 \\
100 \\
150 \\
200\end{array}$ & $\begin{array}{c}36.0 \\
71.6 \\
74.7 \\
118.7 \\
97.5\end{array}$ & $\begin{array}{c}- \\
71.1 \\
38.6 \\
55.1 \\
30.7\end{array}$ & $\begin{array}{c}- \\
29.7 \\
30.7 \\
22.0 \\
24.9\end{array}$ & $\begin{array}{c}- \\
21.2 \\
11.9 \\
12.1 \\
7.7\end{array}$ & $\begin{array}{c}30.3 \\
59.9 \\
75.3 \\
127.9 \\
109.7\end{array}$ & $\begin{array}{c}- \\
59.1 \\
45.0 \\
65.1 \\
39.7\end{array}$ & $\begin{array}{c}- \\
37.0 \\
38.0 \\
26.3 \\
30.3\end{array}$ & $\begin{array}{c}- \\
22.0 \\
17.1 \\
17.1 \\
12.0\end{array}$ \\
\hline & Mean of N-form & 97.0 & 48.9 & 26.8 & 13.2 & 93.2 & 52.2 & 32.9 & 17.1 \\
\hline Calcium nitrate & $\begin{array}{c}0 \\
50 \\
100 \\
150 \\
200\end{array}$ & $\begin{array}{c}36.0 \\
74.6 \\
95.6 \\
108.5 \\
115.8\end{array}$ & $\begin{array}{c}- \\
77.2 \\
59.6 \\
48.3 \\
39.9\end{array}$ & $\begin{array}{c}- \\
33.8 \\
24.2 \\
25.5 \\
22.2\end{array}$ & $\begin{array}{c}- \\
25.9 \\
14.4 \\
12.3 \\
8.9\end{array}$ & $\begin{array}{c}30.3 \\
69.8 \\
81.2 \\
104.8 \\
107.5\end{array}$ & $\begin{array}{c}- \\
79.0 \\
50.9 \\
49.7 \\
38.6\end{array}$ & $\begin{array}{c}- \\
56.5 \\
44.4 \\
38.0 \\
32.0\end{array}$ & $\begin{array}{c}- \\
44.3 \\
22.6 \\
18.8 \\
12.4\end{array}$ \\
\hline & Mean of N-form & 98.6 & 56.2 & 26.4 & 15.4 & 90.8 & 54.6 & 42.7 & 24.5 \\
\hline Mean of N-rate & $\begin{array}{c}0 \\
50 \\
100 \\
150 \\
200\end{array}$ & $\begin{array}{c}36.0 \\
73.1 \\
85.1 \\
113.6 \\
106.7\end{array}$ & $\begin{array}{c}- \\
74.1 \\
49.1 \\
51.7 \\
35.3\end{array}$ & $\begin{array}{l}- \\
31.7 \\
27.4 \\
23.7 \\
23.6\end{array}$ & $\begin{array}{c}- \\
23.5 \\
13.2 \\
12.2 \\
8.3\end{array}$ & $\begin{array}{c}30.3 \\
64.8 \\
78.2 \\
116.4 \\
108.6\end{array}$ & $\begin{array}{c}- \\
69.1 \\
47.9 \\
57.4 \\
39.2\end{array}$ & $\begin{array}{c}- \\
46.8 \\
41.2 \\
32.2 \\
31.1\end{array}$ & $\begin{array}{c}- \\
33.2 \\
19.8 \\
18.0 \\
12.2\end{array}$ \\
\hline F-test & & & & & & & & & \\
\hline & N-form & $\begin{array}{l}* * \\
* * \\
* *\end{array}$ & $\begin{array}{c}* \\
* * \\
*\end{array}$ & n.s. & n.s. & n.s. & $\begin{array}{l}\text { n.s. } \\
* * \\
*\end{array}$ & $\begin{array}{l}* * \\
* * \\
* *\end{array}$ & $\begin{array}{l}* * \\
* * \\
* *\end{array}$ \\
\hline $\mathrm{LSD}_{0.05}$ & $\begin{array}{c}\text { N-form x N-rate } \\
\text { N-form } \\
\text { N-rate } \\
\text { Interaction }\end{array}$ & $\begin{array}{l}* * \\
3.5 \\
5.5 \\
7.8\end{array}$ & $\begin{array}{c}* \\
4.59 \\
7.25 \\
10.25\end{array}$ & $\begin{array}{l}\text { n.s. } \\
2.69 \\
4.26 \\
6.02\end{array}$ & $\begin{array}{l}\text { n.s. } \\
2.02 \\
3.19 \\
4.51\end{array}$ & $\begin{array}{c}\text { n.s. } \\
6.9 \\
10.9 \\
15.4\end{array}$ & $\begin{array}{c}* \\
6.25 \\
9.88 \\
13.97\end{array}$ & $\begin{array}{l}* * \\
2.55 \\
4.04 \\
5.71\end{array}$ & $\begin{array}{c}* * \\
2.23 \\
3.53 \\
4.99\end{array}$ \\
\hline
\end{tabular}
$\left(\mathrm{kg} \mathrm{kg}^{-1}\right)$ of durum wheat as affected by nitrogen $(\mathrm{N})$ fertilisation forms and rates and their combinations, in 2011 and 2012.

$\mathrm{N}$-form, nitrogen fertilisation forms; N-rate, $\mathrm{N}$ fertilisation rates; $\mathrm{N}$ uptake, nitrogen grain uptake; ANR, apparent nitrogen recovery; PE, physiological efficiency; AE, agronomic efficiency; LSD, least significant difference at $\mathrm{P}<0.05 ;{ }^{*} \mathrm{P}<0.05 ; * * \mathrm{P}<0.01 ;$ n.s., not-significant. 


\section{Results and discussion}

\section{Effects of fertilisers on yield, grains protein concen- tration and nitrogen-input efficiency}

The fertiliser N-rate had a significant effect on yield in both growing seasons. Regardless to $\mathrm{N}$-form, yield generally increased as $\mathrm{N}$ rates raised up to $150 \mathrm{~kg} \mathrm{~N} \mathrm{ha}^{-1}$ (Figure 2A and B). As already reported by Garrido-Lestache et al. (2004), this was particularly noticeable in the wettest year (2011), whilst in drier year (2012) the response was only recorded at rates up to $100 \mathrm{~kg} \mathrm{~N} \mathrm{ha}^{-1}$, especially for calcium nitrate. Moreover, we observed slightly higher yields in 2012 with respect to
2011 as well as a greater effect of calcium nitrate than urea. Year-toyear differences in rainfall from October to May, which includes the autumn and spring periods prior to grain-filling, could have had a significant effect on the observed variations in yields. Indeed, LópezBellido et al. (2001) attributed a decrease in wheat yield when rainfall in the September-May period exceeded around $550 \mathrm{~mm}$ (as we observed during 2011), probably due to a poor establishment and development of the crop during the vegetative phase, since the excessive winter rainfall leads to waterlogging in typical medium-clay soil. However, the presence of a layer of crop residues could have mitigated this effect, especially at the highest $\mathrm{N}$-rates. With respect to $\mathrm{N}-\mathrm{form}$, calcium nitrate allowed to obtain higher yields, particularly in 2012 ,

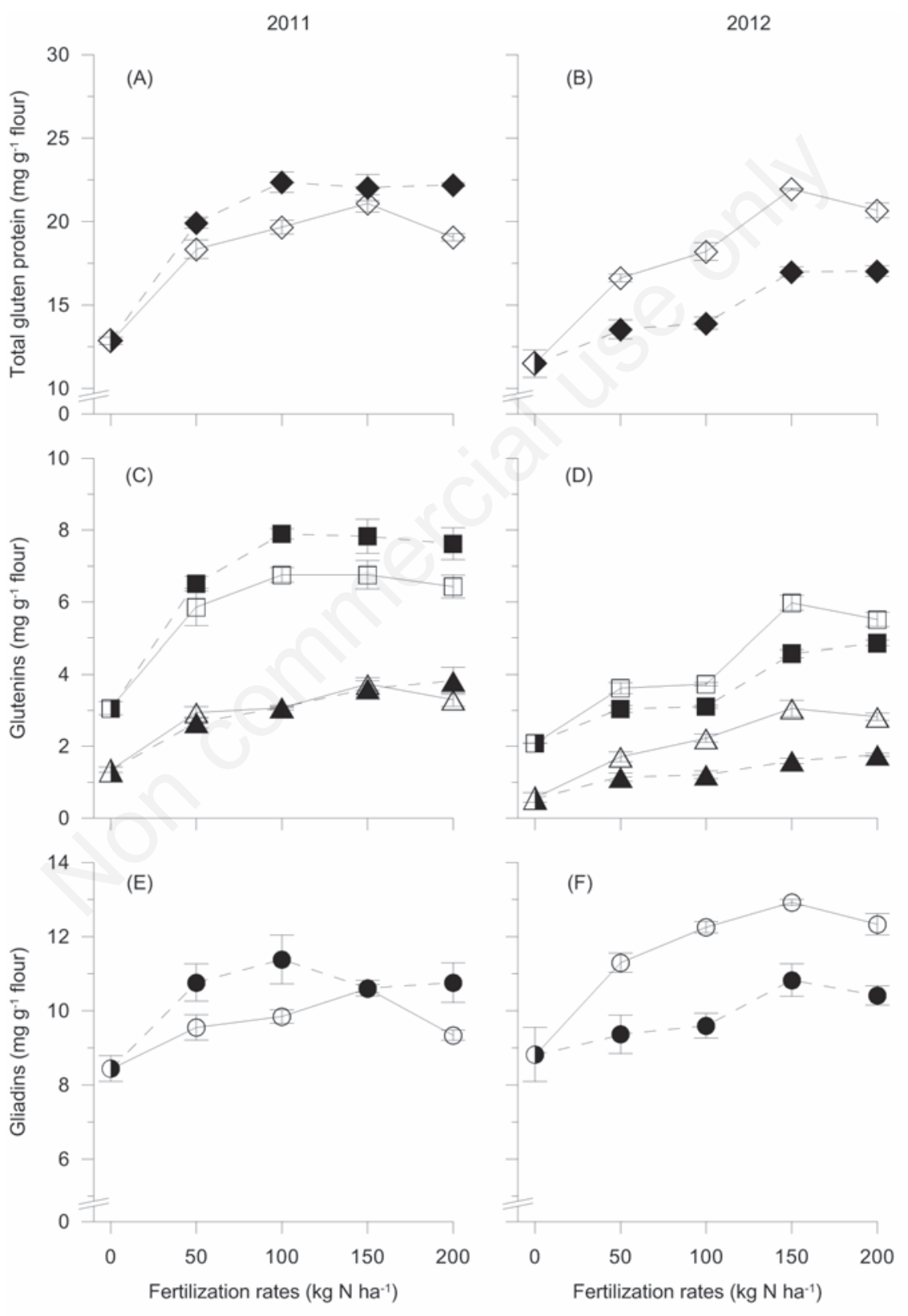

Figure 4. Total gluten proteins ( $\mathrm{mg} \mathrm{g}^{-1}$ flour), gliadins $\left(\mathrm{mg} \mathrm{g}^{-1} \mathrm{flour}\right)$ and glutenins ( $\mathrm{mg} \mathrm{g}^{-1}$ flour) in durum wheat grains against nitrogen $(\mathrm{N})$ fertilisation rates $\left(0,50,100,150\right.$ and $\left.200 \mathrm{~kg} \mathrm{~N} \mathrm{ha}^{-1}\right)$ in 2011 and 2012. Empty symbols stand for urea, black symbols stand for calcium nitrate $(\bullet$, total gluten protein; $\bullet$, gliadins fraction; $\bullet$, low molecular weight glutenins fraction; $\Delta$, high molecular weight glutenins fraction). Data are averages \pm standard errors, for $n=3$ independent replicates. 
when rainfall were mainly located after the second $\mathrm{N}$ application splittime and the higher amount of surface residues ensured a better water retention, reducing nitrate leaching. On the other hand, the higher temperatures recorded in 2012 (i.e. March) may have induced greater loss of $\mathrm{N}$ via $\mathrm{NH}_{3}$ volatilisation (Schoenau and Campbell, 1996) reducing the effectiveness of the less readily available $\mathrm{N}$-form.

In order to synthetise our results, we fitted the exponential and quadratic equations to durum wheat yield data. All the two models significantly explained the relationship between yield and $\mathrm{N}$ fertilisation, as indicated by the higher obtained $\mathrm{R}^{2}$ values ( $\geq 0.93$ ) (Figure $2 \mathrm{~A}$ and B). However, while the exponential model predicts maximum yield when fertiliser application is at infinity (Cerrato and Blackmer, 1990), the quadratic model makes it possible to estimate the $\mathrm{N}$ dose, which correspond to the maximum yield. It diagnosed $\mathrm{N}$ rates for maximum yields below $200 \mathrm{~kg} \mathrm{~N} \mathrm{ha}^{-1}$ for each $\mathrm{N}$ form-year combination; such rates confirm those of De Sanctis et al. (2012) who indicated the dose of $180 \mathrm{~kg} \mathrm{~N} \mathrm{ha}^{-1}$ to obtain a $4 \mathrm{t} \mathrm{ha}^{-1}$ yield in southern Italy, under no tillage. In particular, the model confirmed that the application of calcium nitrate could result in higher yields than urea (2011: 4.17 vs $3.93 \mathrm{t}$ ha $^{-1}$, respectively; 2012: 4.76 vs $4.40 \mathrm{t} \mathrm{ha}^{-1}$, respectively), achieved with $\mathrm{N}$ fertilisation rates of 161 and $153 \mathrm{~kg} \mathrm{~N} \mathrm{ha}^{-1}$ in 2011 and of 138 and $192 \mathrm{~kg} \mathrm{~N} \mathrm{ha}^{-1}$ in 2012 for calcium nitrate and urea, respectively.

The quadratic and exponential models were also applied to describe the GPC response to $\mathrm{N}$ fertilisation rates (Figure $3 \mathrm{~A}$ and $\mathrm{B}$ ). In this

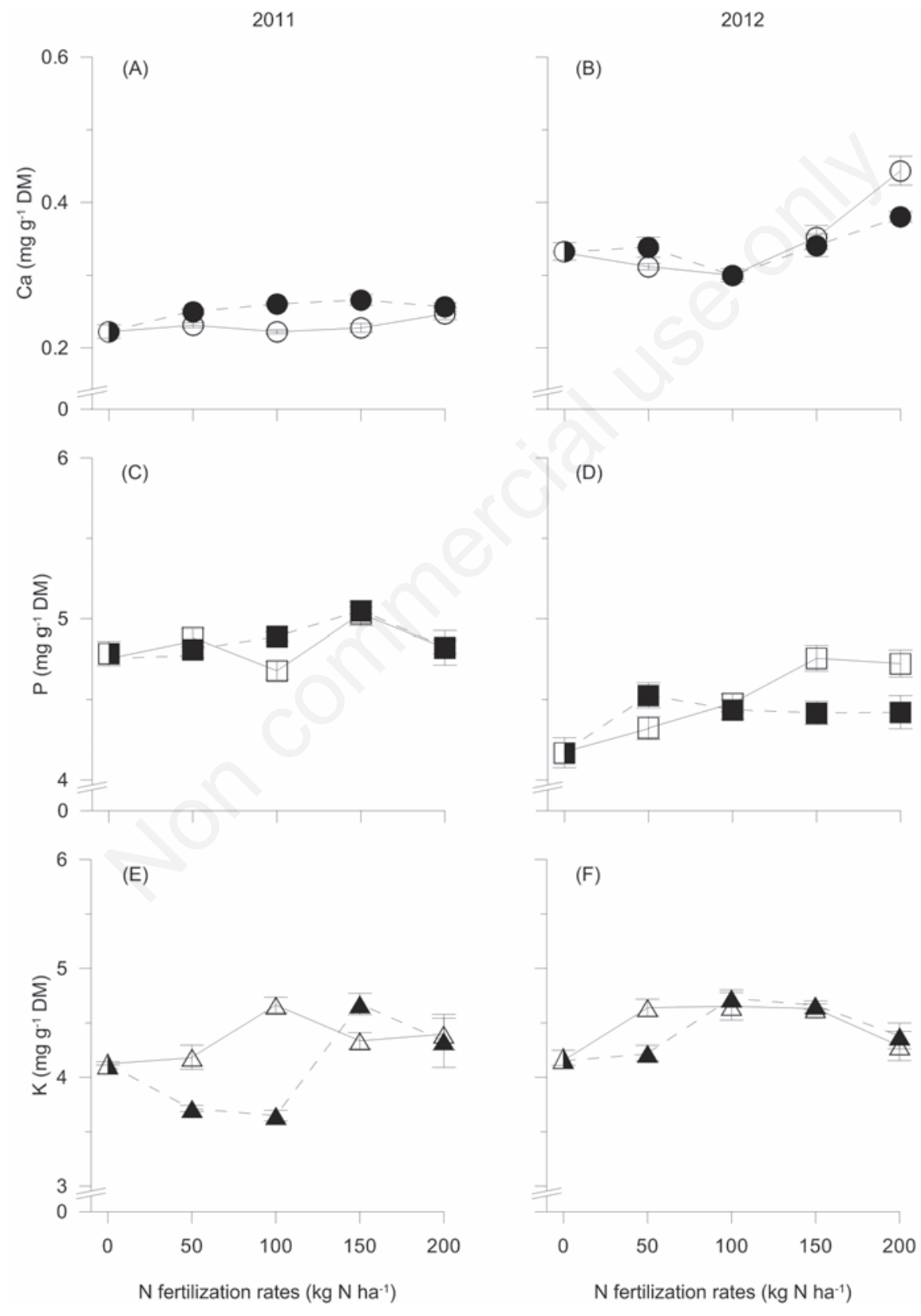

Figure 5. Calcium (Ca) $\left(\mathrm{mg} \mathrm{g}^{-1}\right.$ dry matter, DM), phosphorus $(\mathrm{P})\left(\mathrm{mg} \mathrm{g}^{-1} \mathrm{DM}\right)$ and potassium $(\mathrm{K})\left(\mathrm{mg} \mathrm{g}^{-1} \mathrm{DM}\right)$ concentrations in durum wheat grains against nitrogen $(\mathrm{N})$ fertilisation rates $\left(0,50,100,150\right.$ and $\left.200 \mathrm{~kg} \mathrm{~N} \mathrm{ha}^{-1}\right)$ in 2011 and 2012 . Empty symbols stand for urea, black symbols stand for calcium nitrate $(\bullet, \mathrm{Ca}, \bullet, \mathrm{P} ; \boldsymbol{\Delta}, \mathrm{K})$. Data are averages \pm standard errors, for $\mathrm{n}=3$ independent replicates. 
case, the quadratic equation estimated rational $\mathrm{N}$ fertilisation rates needed to induce the maximum GPC (14.93\% and $14.68 \%$ for urea and calcium nitrate, respectively) only in 2011 (see $\beta_{2}$, Figure 3A) with values from 170.2 to $175.3 \mathrm{~kg} \mathrm{~N} \mathrm{ha}^{-1}$. Such values seem slightly higher than those required to achieve the maximum grain yield, confirming previous findings (Garrido-Lestache et al., 2004). However, similarly to the results of Ryan et al. (1997) and Lloveras et al. (2001) in Mediterranean conditions, we did not generally observe any additional response of GPC at over $150 \mathrm{~kg} \mathrm{~N} \mathrm{ha}^{-1}$. Normally, yield and grain protein content is negatively correlated principally due to the dilution effect (Triboi and Triboi-Blondel, 2002; Stagnari et al., 2013). Nevertheless, this does not imply that higher grain protein cannot be obtained at high-yield levels, as we found a simultaneously increase in both yield and GPC (Garrido-Lestache et al., 2004), probably as a results of an efficient $\mathrm{N}$ translocation to the developing grains.

This was supported by the values of the parameters estimating $\mathrm{N}$ input efficiency, which are shown in Table 1 . Nitrogen uptake $\left(N_{g}\right)$ progressively increased until the doses of 150 and $200 \mathrm{~kg} \mathrm{~N} \mathrm{ha}^{-1}$ for urea and calcium nitrate, respectively. ANR was on average $52.6 \%$ and $53.4 \%$ in 2011 and 2012, respectively and it was always significantly affected by $\mathrm{N}$-form $\mathrm{x} \mathrm{N}$-dose interaction. In general, as the $\mathrm{N}$ doses increased the ANR values decreased. This behaviour was not observed in the case of urea applied at $150 \mathrm{~kg} \mathrm{~N} \mathrm{ha}^{-1}$, probably due to the high protein content both in kernels and straw (data not shown), which allowed to cal-

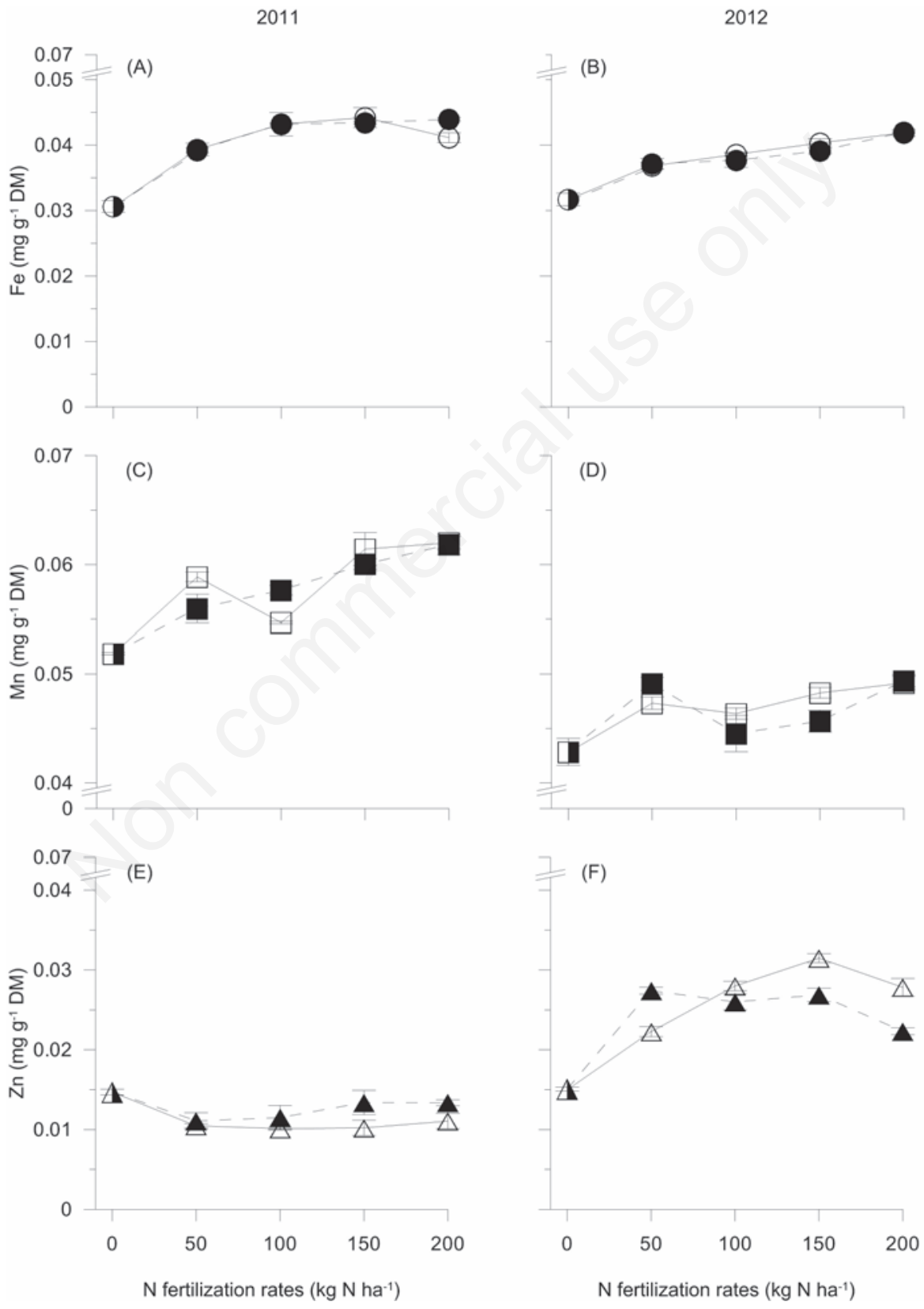

Figure 6. Iron (Fe) ( $\mathrm{mg} \mathrm{g}^{-1}$ dry matter, DM), manganese $(\mathrm{Mn})\left(\mathrm{mg} \mathrm{g}^{-1} \mathrm{DM}\right)$ and zinc $(\mathrm{Zn})\left(\mathrm{mg} \mathrm{g}^{-1} \mathrm{DM}\right)$ concentrations in durum wheat grains against nitrogen $(\mathrm{N})$ fertilisation rates $\left(0,50,100,150\right.$ and $\left.200 \mathrm{~kg} \mathrm{~N} \mathrm{ha}^{-1}\right)$ in 2011 and 2012 . Empty symbols stand for urea, black symbols stand for calcium nitrate $(\bullet, \mathrm{Fe} ; \bullet, \mathrm{Mn} ; \boldsymbol{\Lambda}, \mathrm{Zn})$. Data are averages \pm standard errors, for $\mathrm{n}=3$ independent replicates. 
culate higher $N_{g}$ (i.e., in 2012 , wheat increased $\mathrm{N}$ accumulation of 52.6 $\mathrm{kg} \mathrm{N} \mathrm{ha}^{-1}$ from 100 to $150 \mathrm{~kg} \mathrm{~N} \mathrm{ha}^{-1}$ treatments). This was an unexpected result, since the rates of increase in yield and nutrient uptake are larger at low levels of N-supply, because the nutrient is the primary factor limiting growth (Dobermann, 2007). Conversely, as nutrient supply increases, incremental yield gains become smaller because of the liming effects of other yield determinants. Indeed, modern wheat cultivars tend to develop a few early rather than late tillering culms with an extender tiller life-span, which determine an early peak $\mathrm{N}$-demand (i.e., occurring during the early stages of plant development), when $\mathrm{N}$ input is the main source of supply (Foulkes et al., 1998).

As for ANR, in both years the highest physiological efficiency $\left(\mathrm{P}_{\mathrm{E}}\right)$ values were obtained with the application of $50 \mathrm{~kg} \mathrm{~N} \mathrm{ha}^{-1}$ (31.7 and 46.8 $\mathrm{kg}$ grain per plant's $\mathrm{kg} \mathrm{N}$ actually taken up averaging over $\mathrm{N}$-form, in 2011 and 2012, respectively). Plants agronomic or N-use efficiency $\left(\mathrm{A}_{E}\right)$ progressively lowered with the increasing of $\mathrm{N}$-dose. Averaging over $\mathrm{N}$ form, the values ranged from 23.5 to $8.3 \mathrm{~kg}$ grain per $\mathrm{kg} \mathrm{N}$-input in 2011 and from 33.2 to $12.2 \mathrm{~kg}$ grain per $\mathrm{kg} \mathrm{N}$-input in 2012 . Calcium nitrate allowed obtaining higher $\mathrm{A}_{\mathrm{E}}$ values than urea, confirming previous studies (Guarda et al., 2004; Rahman, et al., 2005). The observed values of indices describing $\mathrm{N}$-input efficiency helped explaining the yield and GPC results, especially with respect to wheatear year-to-year variations. When the rainfall were concentrated prior to anthesis (2012), calcium nitrate treatments gave a better $\mathrm{N}$-use $\left(\mathrm{P}_{\mathrm{E}}\right.$ and $\left.\mathrm{A}_{\mathrm{E}}\right)$ favouring

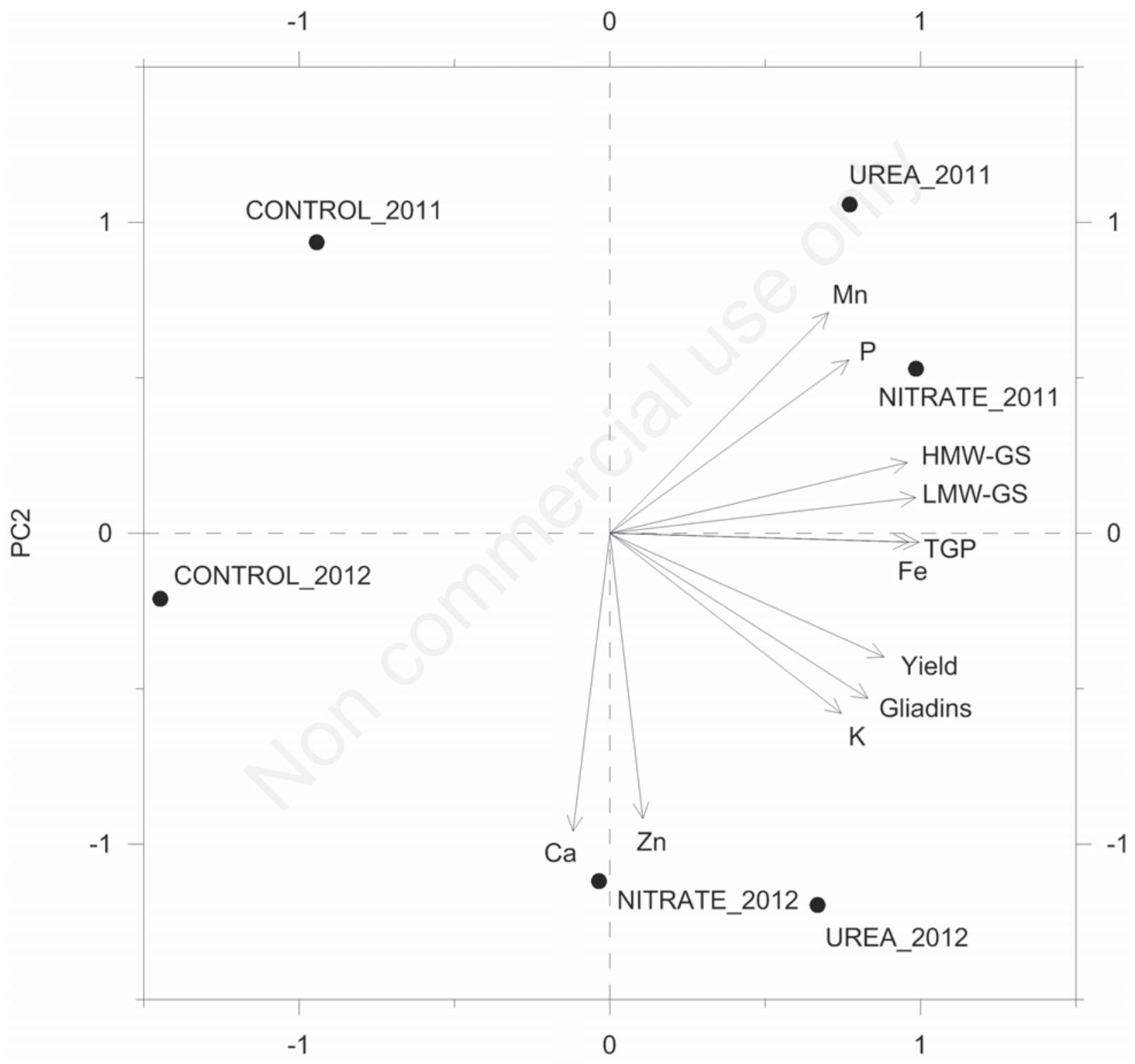

PC1

Figure 7. Two dimensional principal component analysis (PCA) correlation bi-plot: symbols stand for the standardised scores on PC1 (x-axis) and PC2 (y-axis) of six treatments [CONTROL_2011: unfertilised plots, year 2011; CONTROL_2012: unfertilised plots, year 2012; UREA_2011: urea at $150 \mathrm{~kg}$ nitrogen $(\mathrm{N}) \mathrm{ha}^{-1}$, year 2011; UREA_2012: urea at $150 \mathrm{~kg} \mathrm{~N} \mathrm{ha}^{-1}$, year 2012; NITRATE_2011: calcium nitrate at $150 \mathrm{~kg} \mathrm{~N} \mathrm{ha}^{-1}$, year 2011; NITRATE_2012: calcium nitrate at $150 \mathrm{~kg} \mathrm{~N} \mathrm{ha-1,} \mathrm{year} \mathrm{2012];} \mathrm{vectors} \mathrm{represent} \mathrm{the} \mathrm{corre-}$ lations between standardised variables [yield; total gluten proteins (TGP); gliadins; high molecular weight glutenins (HMW-GS); low molecular weight glutenins (LMW-GS); Ca; P; K; Fe; Mn; Zn)] and PCs, in durum wheat. 
higher number of grains per spike (data not shown); when the rainfall were extended through the grain filling period (2011), the efficient use of $\mathrm{N}$ inputs did not depend on $\mathrm{N}$-form. However, the mechanisms underlying the effects of rainfall and soil moisture on wheat yield and quality are complex and the same climatic variables do not consistently have the same effects at all site or in all years (Garrido-Lestache et al., 2004), depending also of the pattern on the mineralisation of organic matter and on crop residues composition. In the short term, crop residues can either increase or decrease the $\mathrm{N}$ availability, according to their C:N ratio (Schoenau and Campbell, 1996). Besides, the quality of a residue is associated to the time it lasts to protect the soil and maintain its physical properties, which also depends on its distribution and geometric arrangement on soil surface (Ordóñez-Fernández et al., 2007). The higher quantity of autumn-winter rainfall recorded during 2011 could have accelerated coriander residues decomposition (Aulakh et al., 1991), with a reduction in its biomass and, consequently, in its potential of soil's hydraulic properties improvement (OrdóñezFernández et al., 2007).

\section{Gluten proteins accumulation}

An increase of $\mathrm{N}$ concentration in grain would normally result in higher gluten protein accumulation (Schipper, 1991) as indicated by the high significant correlation between total $\mathrm{N}$ and gluten proteins content ( $R^{2}$ range from 0.87 to 0.94 , data not shown). Approximately, total gluten proteins increased with $\mathrm{N}$ availability, regardless of $\mathrm{N}$ form, until the dose of $150 \mathrm{~kg} \mathrm{~N} \mathrm{ha}^{-1}$ (Figure $4 \mathrm{~A}$ and B); further $\mathrm{N}$ availability did not induce any additional increase.

The contribution of different gluten protein fractions to the total gluten protein amount was influenced both by year and $\mathrm{N}$ form (Figure 4). In 2011, glutenins and gliadins increased until the dose of $100 \mathrm{~kg} \mathrm{~N} \mathrm{ha}^{-1}$; calcium nitrate performed significantly better in the case of gliadins and LMW-GS. In 2012 glutenins and gliadins increased until the dose of $150 \mathrm{~kg} \mathrm{~N} \mathrm{ha}{ }^{-1}$ with urea inducing significantly higher values of all the gluten fractions, probably due to the higher temperatures during grainfilling - which reduced grain carbohydrate accumulation rather than $\mathrm{N}$ accumulation (Garrido-Lestache et al., 2004) - and higher rainfall in May (López-Bellido et al., 2001). Moreover, gliadin content was stable across the year for calcium nitrate while increased for urea in 2012; glutenins significantly lowered by 27 and $49 \%$ for urea and calcium nitrate, respectively, in 2012. Since the maximum rate of synthesis of glutenins is reported to occur later than that of gliadins for the majority of durum wheat modern genotypes, the late water stress occurred in 2012 was more detrimental on the synthesis of glutenins than gliadins (Saint Pierre et al., 2008). As a consequence, the GS/gliadins ratio reduced in 2012 by $40 \%$ and $47 \%$ for urea and calcium nitrate, respectively. The ratio of polymeric $v s$ monomeric proteins constitutes a criterion for high quality durum wheat (De Vita et al., 2007) and its high values are generally associated with a decrease in extensibility and with an increase in mixing time (MacRitchie, 1985; Mann et al., 2005). The effect of $\mathrm{N}$ dose was significantly more effective on glutenin synthesis, ensuring higher GS/gliadin ratio, matching with recent work which reported differences in the expression of different gluten gene families in response to both $\mathrm{N}$ fertilisation (Hurkman et al., 2013) and genotype (Wan et al., 2013).

\section{Minerals}

The mineral accumulation in durum wheat grains was quite similar in both years of study, except for Mn and Zn, which were lower and higher in 2012 than in 2011, respectively. The effect of $\mathrm{N}$ fertilisation on mineral accumulation in durum wheat grains was not significant or pretty slight in the case of $\mathrm{Ca}, \mathrm{P}, \mathrm{K}$ and $\mathrm{Mn}$ (Figures 5 and 6). Ca averaged $0.29 \mathrm{mg} \mathrm{g}^{-1}, \mathrm{P} 4.66 \mathrm{mg} \mathrm{g}^{-1}$, and $\mathrm{K} 4.48 \mathrm{mg} \mathrm{g}^{-1}$. These results agree with those of Ficco et al. (2009) who found similar mineral concentration in durum wheat modern cultivars. Interestingly, Fe concentrations were increased by $\mathrm{N}$ dose of $44 \%$ and $32 \%$ in 2011 and 2012, respectively; these findings were also observed for $\mathrm{Zn}$ in 2012.

Several authors have already reported a negative correlation between grain yield and grain mineral concentration, suggesting a dilution effect of the starch on minerals (Monasterio and Graham, 2000). We observed a negligible dilution effect, in accordance with other studies which indicated that micronutrient-rich cultivars can also be higher yielding than less micronutrient-rich cultivars (Graham et al., 2001). In particular, Fe and Zn were among those minerals whose contents were not negatively correlated with yield, and their increase in grains can be combined with improved agronomic traits (Monasterio and Graham, 2000; Graham et al., 2001). Since water availability plays a significant role in mineral mobilisation, water deficit can reduce mineral uptake (Oktem, 2008). Probably, under CA system, the management of crop residues and the minimal soil disturbance alleviated drought stress and enhanced water use efficiency (López-Bellido and López-Bellido, 2001). Thus, with higher water and mineral availabilities (Stagnari and Pisante, 2010), wheat plants experienced higher phloem fluxes associated to mineral transportation. It has also been suggested that some micronutrient cations ( $\mathrm{Zn}, \mathrm{Fe}, \mathrm{Cu}$ ) tend to be present in higher levels under zero tillage with residue retentions compared with conventional tillage, especially near the soil surface due to the placement of crop residues starting from the first years of no-till (Franzluebbers and Hons, 1996).

\section{Principal component analysis}

The results of PCA analysis are shown as a two-dimensional correlation bi-plot (Figure 7); the eigenvalues for PC1 and PC2 are 6.79 and 3.48 , respectively, thus capturing $93.4 \%$ of the total data variability (Table 2).

Three groups of variables with high positive correlations within each group can be identified. Yield and gliadins fraction in grains constitute the first group, while TGP, LMW-GS, HMW-GS and Fe the second one in which TGP, LMW-GS and HMW-GS are strongly correlated to PC1 (0.99, 0.98 and 0.96 , respectively); the third group is represented by some minerals i.e., $\mathrm{P}$ and $\mathrm{Mn}$. Ca and $\mathrm{Zn}$ positioned differently when compared to the other variables being negatively correlated to PC2 ( 0.96 and 0.92 , respectively).

The effect of the year clearly emerges from the bi-plot analysis: 2011 (upper half) is distinctively separated by PC2 with respect to 2012 (lower half), independently to $\mathrm{N}$ form. CONTROL is always clearly inde-

Table 2. Principal component scores of the six year-nitrogen $(\mathrm{N})$ form combinations (treatments) and percentage of variation accounted for each principal component; each $\mathrm{N}$-form was applied at $150 \mathrm{~kg} \mathrm{~N} \mathrm{ha}^{-1}$, an unfertilised CONTROL is included.

\begin{tabular}{lcc} 
Theatments & PC1 & PC scores \\
\hline CONTROL_2011 & -2.46 & PC2 \\
CONTROL_2012 & -3.77 & 1.75 \\
\hline UREA_2011 & 2.01 & -0.39 \\
UREA_2012 & 1.74 & 1.98 \\
\hline NITRATE_2011 & 2.57 & -2.23 \\
NITRATE_2012 & -0.09 & 0.99 \\
\hline Percentage explained variation & 61.75 & -2.09 \\
Percentage cumulative variation & 63.04 & 31.66 \\
\hline PC, principal component. & & 94.08 \\
\hline
\end{tabular}


pendent from the fertilisation treatments and is characterised by very different PC1 scores $(-2.46$ and 3.77 for CONTROL_2011 and CONTROL_2012, respectively). Therefore no variable is associated with CONTROL. In 2011 the $150 \mathrm{~kg} \mathrm{~N} \mathrm{ha}^{-1}$ fertilisation rate, regardless of $\mathrm{N}$ form, was associated with high TGP, LMW-GS, HMW-GS, P, Fe and Mn concentration (2.01 and 2.57 PC1 scores for UREA_2011 and NITRATE_2011, respectively), while in 2012 it was associated to $\mathrm{Ca}$ and Zn content in grains. PCA analysis approach was very effective in discriminating yield and quality characteristics with respect to the combination year-N form.

\section{Conclusions}

During the transitional phase to CA in Mediterranean agro-ecosystems, the optimisation of durum wheat yields and grain quality depends strongly on $\mathrm{N}$ fertilisation rates and forms as well as on yearto-year weather variations and residues composition. High yields can be combined with optimal accumulation of total gluten and its fractions as well as with optimum GS/gliadin ratio, with the application of $\mathrm{N}$ rates ranging from 136 to $156 \mathrm{~kg} \mathrm{~N} \mathrm{ha}^{-1}$ of calcium nitrate (as indicated by the quadratic model). In such environmental conditions, nitrate form allows higher $\mathrm{N}$-input efficiency (i.e., $\mathrm{A}_{\mathrm{E}}, \mathrm{P}_{\mathrm{E}}, \mathrm{ANR} \%$ ). Besides, to obtain the highest $\mathrm{N}$ concentrations (14.7\%), higher $\mathrm{N}$ fertilisation doses (around $173 \mathrm{~kg} \mathrm{~N} \mathrm{ha}^{-1}$ ) are needed.

During the transitional phase to CA, the limited amount of crop residues, typical of such dry environments, requires $\mathrm{N}$ application rates not lower than $150 \mathrm{~kg} \mathrm{ha}^{-1}$; as the accumulation of crop residues increases over time the $\mathrm{N}$ fertilisation demand could be likely lowered, as already demonstrated by the available limited data (Rahman et al., 2005), thanks to the recycling of organic $C$ and to long term effects on soil chemical, physical and biological properties.

\section{References}

Abedi T, Alemzadeh A, Kazemeini SA, 2010. Effect of organic and inorganic fertilizers on grain yield and protein banding pattern of wheat. Aust. J. Crop Sci. 4:384-9.

AOAC, 1995. Official methods of analysis, 16th ed. Association of Official Analytical Chemists, methods No. 965.17, 968.08. Washington, DC, USA.

Aulakh MS, Walters DT, Doran JW, Francis DD, Mosier AR, 1991. Crop residue type and placement effects on denitrification and mineralization. Soil Sci. Soc. Am. J. 55:1020-5.

Baggs EM, Stevenson M, Pihlatie M, Regar A, Cook H, Cadisch G, 2003. Nitrous oxide emissions following application of residues and fertiliser under zero and conventional tillage. Plant Soil 254:361-70.

Buri RC, von Reding W, Gavin MH, 2004. Description and characterization of wheat aleurone. Cereal Food. World 49:274-82.

Cerrato ME, Blackmer AM, 1990. Comparison of models for describing corn yield response to nitrogen fertilizer. Agron. J. 82:138-43.

Craswell ET, Godwin DC, 1984. The efficiency of nitrogen fertilizers applied to cereals in different climates. Adv. Plant Nutr. 1:1-55.

De Sanctis G, Roggero PP, Seddaiu G, Orsini R, Porter CH, Jones JW, 2012. Long-term no tillage increased soil organic carbon content of rain-fed cereal systems in a Mediterranean area. Eur. J. Agron. 40:18-27.

De Vita P, Nicosia OLD, Nigro F, Platani C, Riefolo C, Di Fonzo N, Cattivelli L, 2007. Breeding progress in morpho-physiological, agronomical and qualitative traits of durum wheat cultivars released in
Italy during 20th century. Eur. J. Agron. 26:39-53.

Deng XP, Shan L, Zhang HP, Turner NC, 2006. Improving agricultural water use efficiency in arid and semiarid areas of China. Agr. Water Manage. 80:23-40.

Dobermann A, 2007. Nutrient use efficiency-measurement and management. In: Proc. of International Fertilizer Industry Association (IFA) Workshop on Fertilizer Best Management Practices, 7-9 March, Brussels, Belgium, 22 pp.

Dupont FM, Altenbach SB, 2003. Molecular and biochemical impacts of environmental factors on wheat grain development and protein synthesis. J. Cereal Sci. 38:133-46.

Ficco DBM, Riefolo C, Nicastro G, De Simone V, Di Gesù AM, Beleggia R, Platani C, Cattivelli L, De Vita P, 2009. Phytate and mineral elements concentration in a collection of Italian durum wheat cultivars. Field Crop. Res. 111:235-42.

Foulkes MJ, Sylvester Bradley R, Scott RK, 1998. Evidence for differences between winter wheat cultivars in acquisition of soil mineral nitrogen and uptake and utilization of applied fertilizer nitrogen. J. Agr. Sci. 130:29-44.

Franzluebbers AJ, Hons FM, 1996. Soil-profile distribution of primary and secondary plant available nutrients under conventional and no tillage. Soil Till. Res. 39:229-39.

Gao Y, Li Y, Zhang J, Liu W, Dang Z, Cao W, Qiang Q, 2009. Effects of mulch, $\mathrm{N}$ fertilizer, and plant density on wheat yield, wheat nitrogen uptake, and residual soil nitrate in a dryland area of China. Nutr. Cycl. Agroecosys. 85:109-21.

García-Torres L, Benites J, Martinez-Vilela A, Holgado-Cabrera A, 2003. Conservation agriculture: environment, farmers experiences, innovations, socio-economy, policy. Kluwer Academia Publishers, Boston, USA.

Garrido-Lestache E, López-Bellido RJ, López-Bellido L, 2004. Effect of N rate, timing and splitting and $\mathrm{N}$ type on bread-making quality in hard red spring wheat under rainfed Mediterranean conditions. Field Crop. Res. 85:213-36.

Gemtos TA, Galanopoulou S, Kavalaris C, 1998. Wheat establishment after cotton with minimal tillage. Eur. J. Agron. 8:137-47.

Gilbert N, 2012. Dirt poor: the key to tackling hunger in Africa is enriching its soil. The big debate is about how to do it. Nature 483:525-7.

Graham RD, Welch RM, Bouis HE, 2001. Addressing micronutrient malnutrition through enhancing the nutritional quality of staple foods: principles, perspectives and knowledge gaps. Adv. Agron. 70:77-142.

Guarda G, Padovan S, Delogu G, 2004. Grain yield, nitrogen-use efficiency and baking quality of old and modern Italian bread-wheat cultivars grown at different nitrogen levels. Eur. J. Agron. 21:18192.

Hurkman WJ, Tanaka CK, Vensel WH, Thilmony R, Altenbach SB, 2013. Comparative proteomic analysis of the effect of temperature and fertiliser on gliadin and glutenin accumulation in the developing endosperm and flour from Triticum aestivum L. cv. Butte 86 . Proteome Sci. 11:8.

Kassam A, Friedrich T, Shaxson F, Pretty J, 2009. The spread of conservation agriculture: justification, sustainability and uptake. Int. J. Agr. Sustain. 7:292-320.

Knowler D, Bradshaw B, 2007. Farmers' adoption of conservation agriculture: A review and synthesis of recent research. Food Policy $32: 25-48$.

Lloveras J, Lopez A, Ferran J, Espachs S, Solsona J, 2001. Bread-making wheat and soil nitrate as affected by nitrogen fertilization in irrigated Mediterranean conditions. Agron. J. 93:1183-90.

López-Bellido L, López-Bellido RJ, Castillo JE, López-Bellido FJ, 2001. Effects of long-term tillage, crop rotation and nitrogen fertilization on bread-making quality of hard red spring wheat. Field Crop. Res. 72:197-210. 
López-Bellido RJ, López-Bellido L, 2001. Efficiency of nitrogen in wheat under Mediterranean conditions: effect of tillage, crop rotation and N fertilization. Field Crop. Res. 71:31-46.

MacKenzie AF, Fan MX, Cadrin F, 1998. Nitrous oxide emission in three years as affected by tillage, corn-soybean-alfalfa rotations, and nitrogen fertilization. J. Environ. Qual. 27: 698-703.

MacRitchie F, 1985. Studies of the methodology for fractionation and reconstitution of wheat flours. J. Cereal Sci. 3:221-30.

Mann G, Allen H, Morell MK, Nath Z, Martin P, Oliver J, Cullis B, Smith A, 2005. Comparison of small-scale and large-scale extensibility of dough produced from wheat flour. Aust. J. Agric. Res. 56:1387-94.

Monasterio I, Graham RD, 2000. Breeding for trace minerals in wheat. Food Nutr. Bull. 21:392-6.

Morell FJ, Lampurlanés J, Álvaro-Fuentes J, Cantero-Martínez C, 2011. Yield and water use efficiency of barley in a semiarid Mediterranean agroecosystem: long-term effects of tillage and $\mathrm{N}$ fertilization. Soil Till. Res. 117:76-84.

Novoa R, Loomis RS, 1981. Nitrogen and plant production. Plant Soil 58:177-204.

Oktem A, 2008. Effect of water shortage on yield, and protein and mineral compositions of drip-irrigated sweet corn in sustainable agricultural systems. Agr. Water Manage. 95:1003-10.

Ordóñez-Fernández R, Rodríguez-Lizana A, Carbonell R, González P, Perea F, 2007. Dynamics of residue decomposition in the field in a dryland rotation under Mediterranean climate conditions in southern Spain. Nutr. Cycl. Agroecosyst. 79:243-53.

Ottman MJ, Doerge TA, Martin EC, 2000. Durum wheat quality as affected by nitrogen fertilization near anthesis and irrigation during grain filling. Agron. J. 92:1035-41.

Pisante M, 2007. Agricoltura blu. La via italiana dell'agricoltura conservativa: principi, tecnologie e metodi per una produzione sostenibile. Il Sole 24 Ore, Edagricole, Bologna, Italy.

Pisante M, 2013. Agricoltura sostenibile. Principi, sistemi e tecnologie applicate all'agricoltura produttiva per la salvaguardia dell'ambiente e la tutela climatica. Il Sole 24 Ore, Edagricole, Bologna, Italy.

Plaza-Bonil D, Álvaro-Fuentes J, Arrúe JL, Cantero-Martínez C, 2014. Tillage and nitrogen fertilization effects on nitrous oxide yieldscaled emissions in a rainfed Mediterranean area. Agric. Ecosyst. Environ. 189:43-52.

R Development Core Team. 2013. R: A language and environmental for statistical computing. R Foundation for Statistical Computing, Vienna, Austria. Available from: http://www.R-project.org/

Rahman MA, Chikushi J, Saifizzaman M, Lauren JG, 2005. Rice straw mulching and nitrogen response of no-till wheat following rice in Bangladesh. Field Crop. Res. 91:71-81.

Ryan J, Nsarellah N, Mergoum M, 1997. Nitrogen fertilization of durum wheat cultivars in the rainfed area of Morocco: biomass, yield, and quality considerations. Cereal Res. Commun. 25:85-90.

Saint Pierre C, Peterson CJ, Ross AS, Ohm JB, Verhoeven MC, Larson M, Hoefer B, 2008. Winter wheat genotypes under different levels of nitrogen and water stress: changes in grain protein composition. J. Cereal Sci. 47:407-16.

Schipper A, 1991. Modifications of the dough physical proprieties of various wheat cultivars by environmental influences. Agrobiological Res. 44:114-32.

Schoenau JJ, Campbell CA, 1996. Impact of crop residues on nutrient availability in conservation tillage systems. Can. J. Plant Sci. 76:621-6.

Sosulski FW, Imafidon GI, 1990. Amino acid composition and nitrogento-protein conversion factors for animal and plant foods. J. Agric. Food Chem. 38:1351-6.

Singh V, Moreau RA, Doner LW, Eckhoff SR, Hicks KB, 1999. Recovery of fiber in the corn dry grind ethanol process: a feedstock for valuable coproducts. Cereal Chem. 76:868-72.

Stagnari F, Onofri A, Codianni P, Pisante M, 2013. Durum wheat varieties in $\mathrm{N}$ deficient environments and organic farming: a comparison of yield, quality and stability performances. Plant Breed. 132:266-75.

Stagnari F, Pisante M, 2010. Managing faba bean residues to enhance the fruit quality of the melon (Cucumis melo L.) crop. Sci. Hortic. 126:317-23.

Stagnari F, Ramazzotti S, Pisante M, 2010. Conservation agriculture: a different approach for crop production through sustainable soil and water management: a review. In: E. Lichtfouse (Ed.), Organic farming, pest control and remediation of soil pollutants, sustainable agriculture reviews. Springer, Dordrecht Heidelberg London, New York, pp. 55-83.

Tea I, Genter T, Naulet N, Boyer V, Lummerzheim M, Kleiber D, 2004. Effect of foliar sulfur and nitrogen fertilization on wheat storage protein composition and dough mixing properties. Cereal. Chem. 81:759-66.

Triboi E, Triboi-Blondel AM, 2002. Productivity and grain or seed composition: a new approach to an old problem. Eur. J. Agron. 16:163-86.

Visioli G, Comastri A, Imperiale D, Paredi G, Faccini A, Marmiroli N, 2016. Gel-based and gel-free analytical methods for the detection of HMW-GS and LMW-GS in wheat flour. Food Anal. Method. 9:469-76.

Walkley A, Black I, 1934. An examination of the Degtjareff method for determining soil organic matter and a proposed modification of the chromic acid titration method. Soil Sci. 37:29-38.

Wan Y, Shewry RP, Hawkesford J, 2013. A novel family of g-gliadin genes are highly regulated by nitrogen supply in developing wheat grain. J. Exp. Bot. 64:161-8.

Zadoks JC, Chang TT, Konzak CF, 1974. Decimal code for growth stages of cereals. Weed Res. 14:415-21. 